\section{6 \\ SCIENTIFIC ASPECTS OF THE WORK OF THE NATIONAL COAL BOARD}

\author{
By JOHN CROSSLAND \\ Department of Mining, University of Leeds
}

\section{Introduction}

$\mathrm{U}^{\mathrm{N}}$ NDER private ownership, only a few of the larger colliery companies in Britain had laboratories and research departments, and apart from an effort to control the standard of coal preparation, little real scientific investigation was carried out by the colliery companies themselves; at any rate, judged by present-day standards, it was totally inadequate. To some extent, various research organisations-largely sponsored by the Mining Association-compensated partly for this deficiency; but, here again, the scale of attack was not large enough.

When the Miners' Welfare Committee came into being and a levy of $1 d$. per ton of output was arranged, some of this money was used to create the Safety in Mines Research Board. Work carried out by this Board was directed towards increasing the health and safety of those employed in the coal mines of Britain, and much useful work was accomplished. Naturally, the aim was to improve working conditions, study safety appliances and generally to find ways and means of reducing the number of accidents.

There was also the British Coal Owners' Research Association, where some work was done on mine atmospheres, suppression of dust, drilling and spontaneous combustion; but the staff was never large.

Just prior to 1939, the British Coal Utilisation Research Association, to which the Mining Association subscribed most generously, commenced work on a number of programmes connected with the efficient utilization of coal for both domestic and industrial purposes. This organisation was able to assist the various industries in many ways during the war period. It must be remembered that when the National Coal Board took over the vast mining industry of Britain, it did so at comparatively short notice and with almost no preparation for the gigantic task before it. Some of its plans are now being made known, and among them it is not surprising to find that the Coal Board proposes to develop a scientific department in the fullest sense.

Although the organisations mentioned previously were doing useful work before January 1, 1947, it was obvious that considerable expansion would be necessary as deeper, dirtier and more difficult seams were mined. An increase in the amount of mechanization will take place, with a consequent increase in the use of power, both on the surface and under. ground. Therefore, research should be directed towards obtaining a solution to the many problems that will occur, so that plans for the changes can be formulated well ahead, in order to obtain the highest standard of efficiency in all branches of mining work.

In the various coalfields, there has existed for many years, and usually attached to a university department of mining, a coal survey laboratory. These laboratories were financed by the Department of Scientific and Industrial Research, for the purpose
April 10, 1948 Vol. 161

of making chemical analyses and physical examinations of the seams in the area and for providing information of national importance in connexion with the future working of the coal seams. The results of this work have been available to all colliery companies in the past, and the National Coal Board has taken over these laboratories as a going concern, to be placed under the direction of the scientific member of the Board.

\section{Status of Scientific Department}

The National Coal Board decided, from the commencement of its existence, quite rightly, that science should be brought into the mining industry in the fullest sense, and that it should be represented at the highest level. It was not surprising, therefore, to find that Sir Charles Ellis had been appointed as the scientific member of the Board. This was decided so that a scientific approach could be made to all problems, whether under the heading of control or research. It is intended that a scientific organisation shall be built up to become an integral part of the industry, and not something quite extraneous to it.

A divisional 'chief scientist' has been appointed in each division, that is, each coalfield approximately, not as a member of the divisional board, but as an adviser to it. The divisions are split up into areas, and in each area there is a 'scientist' and a staff, so that it will be possible to provide a comprehensive scientific service, which will be at the disposal of the area general mines manager. In time, modern laboratories and equipment will be available in all coalfields, and, when the necessary staff can be obtained, much useful work may be accomplished in a field where there is a wide scope for work of this kind. Eventually, at the divisional level, laboratories will be available, with a specialist staff, to tackle problems which are beyond the resources of the area laboratories, and which are of special interest to the particular division. In this connexion, it should be mentioned that each coalfield has its own particular problems; for example, South Wales, production and suppression of dusts which cause pneumoconiosis ; Staffordshire, Warwickshire and South Yorkshire, spontaneous heating and gob fires; West Yorkshire, working thin seams; north of England, preparation and cleaning of gas coals.

There are many problems which are found in all coalfields: pit heap fires, treatment of effluents, testing of suggested new analytical methods, the routine examination of the prepared coal and coal preparation problems generally. Routine scientific work includes analysis of coal, mine air, mine dusts, cokes, oil and metals, physical tests on coal, analysis and treatment of water (particularly for boiler plants and in some instances for domestic use).

In an effort to decentralize the scientific control service, it is intended that the day-to-day work of control should be determined by the division, in accordance with standard methods and standards of accuracy laid down by the Board. This is so that laboratories will be similar in status, arrangements and staff. A 'director of scientific control' has been appointed to co-ordinate the work in the various divisions.

As mentioned previously, the national coal survey has been transferred to the Coal Board, and the laboratories will co-operate with the divisional scientific organisations, with the Geological Survey and with the Fuel Research Station at Greenwich. 


\section{National Research Directorates}

Mainy of the research problems concern all the coalfields of Britain, and therefore cannot be investigated at divisional level. In order to obtain the maximum of efficiency, the full weight of the headquarters staff will be necessary to deal with these problems. Provisionally, three research directors have been appointed at national level : $(a)$ chemical, (b) medical, (c) physical. Under $(a)$, much of the long-term research will be on the "physics and chemistry' of coal, the carbonization and manufacture of special fuels and the development of ehemicals from the by-products of coke and gas. The majority of this work will be carried out at Newcastle and in South Wales, and will be co-related with that of the British Coal Utilisation Research Association, where work is being done on the efficient utilization of coal. Under (b) the chief problem will be the health of the miner. The present director is a physician, and in the first place investigation will be made on such occupational diseases as pneumoconiosis, nystagmus, dermatitis, rheumatism, beat-hand and beat-knee. There are in existence organisations which have already carried out some work on these diseases; but much can be done by co-ordinating their efforts, and in the dissemination of knowledge obtained. Very often the latest information never reaches the miner, who, like many men employed in rather rough and tough jobs, tends to be careless about his health. Statistics relating to diseases and accidents will be examined, and special men and collieries will be selected for experimental purposes, as these problems have to be considered from the medical, physiological and operational points of view. An effort is being made to recruit an adequate and properly qualified staff.

\section{General Research}

It is important that all questions of a fundamental character which affect underground working conditions should be investigated. In the first place, the 'director of general research' is concentrating on mine dusts and illumination. With regard to the latter, for example, it is necessary to produce lighting of a character which is suitable for different coal faces. Pneumatic fluorescent lamps are being tried, and, generally, mine lights of numerous types are being studied in relation to the various methods of working, which include the use of many classes of machinery. It is obvious this work has considerable bearing on the prevention and alleviation of certain diseases such as pneumoconiosis and miners' nystagmus. The National Coal Board has taken over all the liabilities of the Mining Association with regard to research, and therefore becomes the largest subscribing member of the British Coal Utilisation Research Associa. tion. Sir Charles Ellis has been elected president and chairman of the council of the Association. This will allow of the necessary liaison between these large organisations and will ensure that all research work on coal will be co-ordinated, and much overlapping of programmes of research thus avoided. In order to facilitate the interchange of ideas between the Board and the research organisation, the scientific member's deputy-the director-general of research-has been made responsible for the efficient organisation of the seientific aspect of the Coal Board's work, and a small staff will be engaged on routine administration, so that the scientific workers employed will be free from restrictions of this kind.
The ground work has been accomplished, and much of the machinery created for the scientific study of the British coal industry's problems; but it is premature yet to look for major results. There is unlimited scope for the Scientific Department when it is properly equipped and staffed.

\section{THE FUTURE OF THE NEW FOREST}

$T$ HERE is probably no part of England which is the subject of more general interest than the New Forest. Everyone in the country has become acquainted as a child with at least one historical fact associated with the New Forest, and has since acquired some information-probably inaccuratoas to the real significance of both parts of its name; even if he has never visited it, he feels that it is part of the national heritage which should be preserved as such.

Those who live in or near the Forest, those who know it well as visitors, and those who have some part to play in its use and maintenance, have naturally all been keenly interested in the effect moderm developments and ideas are having or may in future have on it; and the result has been a series of official publications on these subjects - as well as numerous unofficial reports and papers-of which the latest is the "Report of the New Forest Committee, 1947"*. The Committee in question was appointed by H.M. Forestry Commission in April 1946, "to investigate the state and condition of the New Forest and, having due regard to existing rights and interests, to recommend such measures as they consider desirable and necessary for adjusting the Forest to modern requirements". The membership of the Committee should be noted, comprising a distinguished repre. sentative each of the English National Committee of the Forestry Commission, of the Council for the Preservation of Rural England, and of the Forestry Commission itself, under the chairmanship of the Right Hon. H. T. Baker. From the list of eighty-four witnesses heard, it is evident, despite one or two gaps, that every effort was made to hear all informed and interested points of view-and incidentally the Committee met no fewer than thirty-five times.

The two committees responsible for the previous reports of 1939 (Report of the Committee of Planning Officers, 1938-39, H.M.S.O.) and 1945 (Planning Officers Report; Planning Committees Revision, 1945 ; New Forest Advisory Planning Committee, Lyndhurst) were primarily composed of representatives of the local government authorities most concerned, and dealt specifically with the protection of the New Forest as related to local and regional planning. The deputy-surveyor, Mr. D. Young, has served on all three committees, and much of the credit is due to him for the very considerable measure of success attained in reconciling rather conflicting views and interests, and the significant improvement of the relations between the major interests which has been brought about in recent years.

This is perhaps not the place to examine the legal aspects of the problem, important and interesting though they are; but it must be noted that the present situation is mainly governed by the New

* Forestry Commission. Report of the New Forest Committee, 1947 Pp. 104. (Cmd. 7245.) (London: H.M. Stationery Office, 1947.) 38. $6 d$. net. 